\title{
WYNIKI EKONOMICZNO-FINANSOWE GOSPODARSTW Z UPRAWAMI POLOWYMI NA TLE GOSPODARSTW NASTAWIONYCH NA POZOSTAŁĄ PRODUKCJĘ ROŚLINNĄ ORAZ GOSPODARSTW OGÓŁEM W POLSCE
}

\author{
Michat Figura \\ Katedra Agronomii Szkoły Głównej Gospodarstwa Wiejskiego w Warszawie \\ Kierownik katedry: dr hab. Irena Suwara
}

\begin{abstract}
Słowa kluczowe: typ rolniczy, produkcja roślinna, dochód z rodzinnego gospodarstwa rolnego Key words: type of farming, crops production, family farm income

S y n o p s i s. W opracowaniu zaprezentowano wyniki ekonomiczno-finansowe gospodarstw rolnych nastawionych na uprawę roślin polowych na tle gospodarstw ukierunkowanych na pozostałą produkcję roślinną (uprawy ogrodnicze, uprawy trwałe) oraz gospodarstw ogółem w Polsce. Podstawę badań stanowily dane z lat 2013-2014 zebrane w ramach Polskiego FADN. Wykazano, że gospodarstwa, w których dominujący udział w wartości produkcji ogółem stanowi uprawa roślin polowych (głównie zbóż i rzepaku), odznaczały się średnio o około $20 \%$ wyższym dochodem niż gospodarstwa ogółem. Pod względem dochodu dominowały gospodarstwa ogrodnicze przy zaobserwowanym zróżnicowaniu regionalnym. Gospodarstwa ogrodnicze cechowała stosunkowo niewielka wartość pozyskanych dopłat, które w pozostałych typach roślinnych oraz gospodarstwach ogółem wywierały znaczący wpływ na uzyskane dochody.
\end{abstract}

\section{WSTĘP}

Ukierunkowanie gospodarstwa na prowadzenie określonych działalności produkcji rolnej w głównej mierze wynika z warunków przyrodniczych, a także posiadanego parku maszyn i możliwości zbytu wyprodukowanych produktów rolnych. W dobie postępu technicznego umiejętności zarządzającego są postrzegane jako kluczowe. Z kolei wybór kierunków produkcji istotnie wpływa na wyniki ekonomiczne i finansowe gospodarstwa, szczególnie jego dochodowość [Figura 2012]. Porównanie gospodarstw pod tym kątem oraz ukazanie różnic w dochodzie będącym wypadkową m.in. takich składowych, jak wartość produkcji, poniesione koszty oraz wysokość pozyskanych dopłat związanych z działalnością operacyjną gospodarstwa, możliwe jest dzięki danym pozyskanym w gospodarstwach w ramach Polskiego FADN. Jest to system obowiązujący w każdym państwie członkowskim Unii Europejskiej (UE), którego głównym celem jest monitorowanie efektów wspólnej polityki rolnej.

Celem pracy jest porównanie sytuacji ekonomiczno-finansowej towarowych gospodarstw należących do typu ,uprawy polowe” na tle gospodarstw w typie „uprawy ogrodnicze” i „uprawy trwałe” oraz gospodarstw ogółem w Polsce. Analizę przeprowadzono na podstawie danych Polskiego FADN zebranych w latach 2013-2014. 


\section{MATERIAŁ I METODYKA}

Grupowanie gospodarstw według typu rolnego (nastawienia produkcyjnego) umożliwia porównywanie przedsiębiorstw rolnych o różnym kierunku produkcji pod względem wyników ekonomicznych i finansowych. W obowiązującym jednolitym we wszystkich krajach Wspólnoty systemie FADN wydzielane są one na podstawie udziału standardowej produkcji (ang. Standard Output - $S \mathrm{O}^{1}$ ) poszczególnych działalności rolniczych w tworzeniu całkowitej wartości SO w gospodarstwie.

$\mathrm{W}$ metodyce stosowanej w Polsce w systemie zbierania i wykorzystywania danych rachunkowych z gospodarstw rolnych, zwanym Polskim FADN, według kryterium SO gospodarstwa klasyfikuje się na 8 podstawowych typów rolniczych. W zależności od ukierunkowania produkcyjnego są to następujące typy gospodarstw rolnych: ,uprawy polowe”, „uprawy ogrodnicze”, „uprawy trwałe”, „winnice”, „krowy mleczne”, „zwierzęta trawożerne”, ,zwierzęta ziarnożerne” oraz gospodarstwa mieszane. W opracowaniu porównywano gospodarstwa nastawione na produkcję roślinną (typ „uprawy polowe” - gospodarstwa z produkcja polową, ,uprawy ogrodnicze” - gospodarstwa ogrodnicze, „uprawy trwałe” - gospodarstwa z produkcją upraw trwałych) oraz gospodarstwa ogółem. Według FADN, do grupy gospodarstw w typie ,uprawy polowe” zalicza się gospodarstwa, w których największą wartość produkcji stanowi produkcja uzyskana głównie z uprawy zbóż i rzepaku. Typ ,uprawy ogrodnicze” tworzą gospodarstwa wyspecjalizowane w uprawie warzyw i kwiatów, produkowanych zarówno w uprawie polowej, jak i pod osłonami wysokimi, tj. w szklarniach, tunelach foliowych (powyżej 1,5 m w szczycie) i inspektach oraz w produkcji grzybów. Natomiast do typu „uprawy trwałe” zaliczane są sady i plantacje wieloletnie, które w Polsce, w środowisku rolniczym także traktowane są raczej jako gospodarstwa ogrodnicze.

W badaniach wykorzystano dane z lat 2013-2014 z uwagi na podobną liczbę gospodarstw w próbie oraz brak różnic w powierzchni użytków rolnych pomiędzy latami w gospodarstwach ogółem oraz $\mathrm{w}$ danym typie $\mathrm{z}$ produkcją roślinną. Wyniki ekonomiczne przedstawione w pracy są średnimi ważonymi dla gospodarstw w trzech typach z produkcją roślinną oraz w gospodarstwach ogółem w Polsce w zależności od regionów wydzielonych na potrzeby FADN. Podział Polski na regiony zaprezentowano w tabeli 1., natomiast w tabeli 2. przedstawiono rozkład gospodarstw w poszczególnych regionach oraz liczbę gospodarstw, które je reprezentowały. Dla gospodarstw w danym typie oraz regionie kraju zaprezentowano poszczególne składowe mające wpływ na wartość wypracowanego dochodu (wartość produkcji, koszty jej wytworzenia, dopłaty pozyskane w ramach działalności operacyjnej). Analizę danych poprzedzono ogólną charakterystyką gospodarstw pod względem posiadanych zasobów czynników wytwórczych (powierzchnia użytków rolnych, nakłady pracy, wartość aktywów).

Ze względu na fakt, że w gospodarstwach ogrodniczych znaczna część roślin uprawiana jest pod osłonami wysokimi, w których rośliny na tej samej powierzchni mogą być uprawiane kilka razy w ciągu roku, w opracowaniu nie przedstawiono wyników w przeliczeniu na 1 ha użytków rolnych (UR), natomiast zaprezentowano je w odniesieniu do całego gospodarstwa będącego w danym typie.

Standardowa produkcja jest średnią z 5 lat wartością produkcji określonej działalności produkcji roślinnej lub zwierzęcej, uzyskaną z 1 ha lub od 1 zwierzęcia w ciągu 1 roku, w przeciętnych dla danego regionu warunkach produkcyjnych [Goraj i in. 2010]. Klasyfikacja według tego kryterium obowiązuje od 2010 roku. 
Tabela 1. Podział Polski na regiony rolnicze według Polskiego FADN

\begin{tabular}{|c|c|c|}
\hline Oznaczenie & Nazwa & Województwa \\
\hline Region A & Pomorze i Mazury & $\begin{array}{l}\text { lubuskie, pomorskie, zachodniopomorskie, } \\
\text { warmińsko-mazurskie }\end{array}$ \\
\hline Region B & Wielkopolska i Śląsk & $\begin{array}{l}\text { dolnośląskie, opolskie, wielkopolskie, } \\
\text { kujawsko-pomorskie }\end{array}$ \\
\hline Region $\mathrm{C}$ & Mazowsze i Podlasie & mazowieckie, podlaskie, łódzkie, lubelskie \\
\hline Region D & Małopolska i Pogórze & podkarpackie, małopolskie, świętokrzyskie, śląskie \\
\hline
\end{tabular}

Źródło: [Floriańczyk i in. 2016].

Tabela 2. Populacja i próba* gospodarstw rolnych w latach 2013-2014 według typów rolniczych w regionach FADN

\begin{tabular}{|c|c|c|c|c|c|c|c|c|c|}
\hline \multirow[t]{3}{*}{ Zmienna } & \multirow[t]{3}{*}{ Region } & \multirow{2}{*}{\multicolumn{2}{|c|}{$\begin{array}{c}\text { Liczba gospodarstw } \\
\text { w roku }\end{array}$}} & \multicolumn{6}{|c|}{ Liczba gospodarstw w typie w roku } \\
\hline & & & & \multicolumn{2}{|c|}{$\begin{array}{l}\text { uprawy } \\
\text { polowe }\end{array}$} & \multicolumn{2}{|c|}{$\begin{array}{l}\text { uprawy } \\
\text { ogrodnicze }\end{array}$} & \multicolumn{2}{|c|}{$\begin{array}{l}\text { uprawy } \\
\text { trwałe }\end{array}$} \\
\hline & & 2013 & 2014 & 2013 & 2014 & 2013 & 2014 & 2013 & 2014 \\
\hline \multirow{5}{*}{ 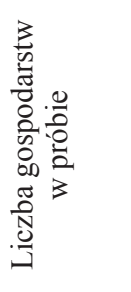 } & PL & 12322 & 12330 & 3215 & 3342 & 364 & 349 & 439 & 432 \\
\hline & A & 1929 & 1940 & 681 & 717 & 29 & 23 & $14^{* *}$ & 15 \\
\hline & B & 4446 & 4449 & 1402 & 1451 & 90 & 81 & 46 & 40 \\
\hline & $\mathrm{C}$ & 4513 & 4498 & 786 & 818 & 155 & 150 & 287 & 285 \\
\hline & $\mathrm{D}$ & 1434 & 1443 & 346 & 356 & 90 & 95 & 92 & 92 \\
\hline \multirow{5}{*}{ 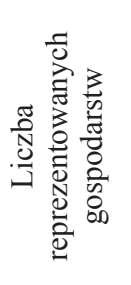 } & PL & 730905 & 730861 & 145024 & 145011 & 28675 & 30278 & 33955 & 33530 \\
\hline & A & 80899 & 80899 & 25667 & 25665 & 1490 & 1270 & 2154 & 1748 \\
\hline & B & 171418 & 171403 & 47742 & 47745 & 6305 & 8150 & 2258 & 2228 \\
\hline & $\mathrm{C}$ & 332568 & 332541 & 49916 & 49891 & 12721 & 12699 & 23770 & 23819 \\
\hline & D & 146021 & 146018 & 21700 & 21710 & 8159 & 8159 & 5774 & 5735 \\
\hline
\end{tabular}

* Każde gospodarstwo rolne prowadzące rachunkowość w Polskim FADN w danym roku reprezentuje pewną liczbę podobnych gospodarstw ze swojej warstwy. Próba gospodarstw rolnych dla pola obserwacji Polskiego FADN jest reprezentatywna ze względu na 3 kryteria: lokalizację (regiony FADN), wielkość ekonomiczną i typ rolniczy. W pracy dokonano podziału ze względu na region oraz typ rolniczy. Gospodarstwo, aby mogło być włączone do badań musi przekroczyć minimalny próg wielkości ekonomicznej, wyrażony od 2010 r. w euro standardowej produkcji (SO). Próg ten ustalany jest w taki sposób, aby w polu obserwacji znalazły się gospodarstwa rolne wytwarzające $90 \%$ SO.

** Zgodnie z metodyką FADN, wyniki można prezentować wyłącznie jako średnie pochodzące z co najmniej 15 gospodarstw rolnych, aby zapewnić anonimowość i ochronę danych osobowych; $\mathrm{z}$ uwagi na zbyt małą liczbę gospodarstw w typie uprawy trwałe w regionie A zaprezentowane wyniki dotyczyły tylko $2014 \mathrm{r}$.

Źródło: baza danych Polskiego FADN. 


\section{WYNIKI BADAŃ}

\section{OGÓLNA CHARAKTERYSTYKA GOSPODARSTW}

Czynnikami decydującymi o możliwościach produkcyjnych gospodarstwa są m.in.: zasoby ziemi, pracy oraz aktywów. W UE potencjał ten określany jest mianem wielkości ekonomicznej gospodarstwa, która zgodnie z danymi zamieszczonymi w tabeli 3., średnio w gospodarstwach ogółem w Polsce wynosiła 25 tys. euro i była wyższa od wielkości ekonomicznej gospodarstw ukierunkowanych na produkcję upraw polowych o 3,7 tys. euro. Najwyższy poziom wielkości ekonomicznej osiągały gospodarstwa ogrodnicze, a najniższy gospodarstwa z produkcją upraw trwałych. Oznacza to, że gospodarstwa ogrodnicze na tle pozostałych typów z produkcją roślinną oraz gospodarstw ogółem cechowały się najwyższą zdolnością do wytwarzania produkcji.

Tabela 3. Wybrane informacje dotyczące produkcji w gospodarstwach z uprawami polowymi na tle pozostałych typów z produkcją roślinną oraz gospodarstw ogółem w Polsce (średnio $\mathrm{z}$ lat 2013 i 2014) według regionów FADN

\begin{tabular}{|c|c|c|c|c|c|}
\hline \multirow[t]{2}{*}{ Typ gospodarstwa } & \multirow[t]{2}{*}{ PL } & \multicolumn{4}{|c|}{ Region } \\
\hline & & A & $\mathrm{B}$ & $\mathrm{C}$ & $\mathrm{D}$ \\
\hline \multicolumn{6}{|c|}{ Wielkość ekonomiczna [euro] } \\
\hline Uprawy polowe & 21303 & 34120 & 26342 & 12784 & 14649 \\
\hline Uprawy ogrodnicze & 43678 & 71915 & 48109 & 45215 & 32628 \\
\hline Uprawy trwałe & 17693 & 30086 & 24111 & 17443 & 12985 \\
\hline Ogółem & 25025 & 36613 & 37095 & 20339 & 15108 \\
\hline \multicolumn{6}{|c|}{ Powierzchnia użytków rolnych [ha] } \\
\hline Uprawy polowe & 29,4 & 55,9 & 33,4 & 17,7 & 15,9 \\
\hline Uprawy ogrodnicze & 5,7 & 10,4 & 5,8 & 6,7 & 3,4 \\
\hline Uprawy trwałe & 9,8 & 20,8 & 13,4 & 9,3 & 7,8 \\
\hline Ogółem & 19,9 & 38,5 & 27,5 & 15,5 & 10,6 \\
\hline \multicolumn{6}{|c|}{ Nakłady pracy ogółem [AWU] } \\
\hline Uprawy polowe & 1,569 & 1,691 & 1,593 & 1,519 & 1,487 \\
\hline Uprawy ogrodnicze & 2,675 & 3,662 & 2,940 & 2,309 & 2,848 \\
\hline Uprawy trwałe & 2,135 & 1,986 & 2,392 & 2,148 & 1,982 \\
\hline Ogółem & 1,730 & 1,848 & 1,879 & 1,665 & 1,640 \\
\hline \multicolumn{6}{|c|}{ Nakłady pracy najemnej [AWU] } \\
\hline Uprawy polowe & 0,239 & 0,366 & 0,317 & 0,156 & 0,112 \\
\hline Uprawy ogrodnicze & 1,095 & 1,887 & 1,445 & 0,717 & 1,232 \\
\hline Uprawy trwałe & 0,738 & 0,701 & 1,256 & 0,749 & 0,472 \\
\hline Ogółem & 0,236 & 0,335 & 0,418 & 0,155 & 0,154 \\
\hline \multicolumn{6}{|c|}{ Aktywa [zł] } \\
\hline Uprawy polowe & 830026 & 1191067 & 1035136 & 593662 & 495420 \\
\hline Uprawy ogrodnicze & 556683 & 762258 & 673727 & 504584 & 502847 \\
\hline Uprawy trwałe & 696549 & 662071 & 824632 & 712813 & 594328 \\
\hline Ogółem & 713601 & 1022565 & 995745 & 616482 & 432404 \\
\hline
\end{tabular}

Źródło: obliczenia własne na podstawie danych Polskiego FADN oraz [Cholewa, Kambo 2016, Goraj, Tarasiuk 2016, Mikołajczyk, Wituszyńska 2016, Puchalska i in. 2016] 
Gospodarstwa z dominującym udziałem upraw polowych dysponowały największą powierzchnią użytków rolnych, która wynosiła średnio w kraju 29,4 ha i była o 47,5\% większa w porównaniu z gospodarstwami ogółem. Gospodarstwa ogrodnicze oraz wyspecjalizowane w produkcji upraw trwałych (sadów i plantacji wieloletnich) dysponowały stosunkowo niewielką powierzchnią użytków rolnych, odpowiednio o 23,7 i 19,6 ha mniej w porównaniu z gospodarstwami z produkcją polową.

Cechą różnicującą gospodarstwa znajdujące się w danym typie produkcyjnym oraz regionie kraju są także nakłady pracy. W gospodarstwach z dominującym udziałem upraw polowych nakłady pracy w przeliczeniu na osobę pełnozatrudnioną były podobne jak w gospodarstwach ogółem, natomiast w pozostałych typach gospodarstw ukierunkowanych na produkcję roślinną proces produkcyjny wymaga większego zaangażowania siły roboczej. Największymi nakładami pracy odznaczały się gospodarstwa ogrodnicze, gdzie średnio w kraju wynosiły one $2,68 \mathrm{AWU}^{2}$, z czego $40,9 \%$ stanowiła praca najemna przy 1,6 osoby zatrudnionej w gospodarstwach polowych i zaledwie $15,2 \%$ udziału pracy najemnej, gdzie były najniższe. Ponaddwukrotnie mniejszy udział pracy najemnej w zasobach pracy ogółem w gospodarstwach z dominacją upraw polowych wynika z faktu, że zboża i rzepak należą do roślin o prostej technologii produkcji, tj. niewymagających znacznych nakładów pracy, czyli roślin o małej pracochłonności oraz kosztochłonności. Ograniczanie nakładów wynika m.in. z możliwości pozyskania produktów przez zbiór kombajnowy.

Pod względem wartości aktywów (zasoby majątkowe o określonej wartości będące we władaniu gospodarstwa) dominowały gospodarstwa z uprawami polowymi. Warto zaznaczyć, że wynika to w głównej mierze z większej powierzchni ziemi w tych gospodarstwach. Szczególnie dotyczy to regionu A, tj. regionu o największej średniej powierzchni użytków rolnych w kraju, która w tym regionie jest największa niezależnie od typu produkcyjnego.

\section{WARTOŚĆ PRODUKCJI}

Wartość produkcji uzyskana przez gospodarstwa z produkcją polową była najbardziej zbliżona do gospodarstw ogółem w Polsce. Pomiędzy gospodarstwami w pozostałych typach istniały znaczące różnice w uzyskanej wartości produkcji (tab. 4.). Przeciętnie w gospodarstwach z uprawami ogrodniczymi była ona ponadpółtorakrotnie wyższa od wartości, którą osiągnęły gospodarstwa ogółem, a także gospodarstw z produkcją polową oraz ponaddwukrotnie wyższa od wartości produkcji w grupie gospodarstw ukierunkowanych na uprawy trwałe. Różnice te wyraźnie zależały od regionu, przy czym tylko w jednym z regionów (Pomorze i Mazury) gospodarstwa z produkcją polową uzyskały wyższą wartość produkcji niż gospodarstwa ogółem.

Cechą gospodarstw z produkcją polową wyróżniającą je na tle gospodarstw ogółem w Polsce jest fakt, że praktycznie cała $(93,6 \%)$ wartość produkcji pochodziła z produkcji roślinnej, a tylko $6,4 \%$ z produkcji zwierzęcej oraz produkcji innej niż roślinna i zwierzęca, tj. tzw. produkcji pozostałej ${ }^{3}$. W pozostałych typach gospodarstw z produkcją roślinną

2 AWU (ang. Annual Work Unit) - jednostka przeliczeniowa pracy; ekwiwalent czasu przepracowanego przez jedną osobę pełnozatrudnioną w ciągu roku w gospodarstwie rolnym; od 2012 r. wynosi 2120 godzin pracy wykonanej przez rolnika, członków jego rodziny oraz wszystkich pracowników najemnych w ciągu roku.

3 Produkcję pozostałą (pozostałe przychody z działalności operacyjnej gospodarstwa rolnego) tworzą: produkcja leśna, produkcja nierolnicza, usługi świadczone własnym sprzętem na zewnątrz gospodarstwa rolnego, usługi agroturystyczne, usługi własne na rzecz inwestycji gospodarstwa rolnego, czynsze dzierżawne, odszkodowania produkcyjne. 
Tabela 4. Wybrane kategorie produkcji, kosztów i dochodów oraz dopłat dla gospodarstw z uprawami polowymi na tle pozostałych typów z produkcją roślinną oraz gospodarstw ogółem w Polsce (średnio z lat 2013 i 2014) według regionów FADN

\begin{tabular}{|c|c|c|c|c|c|}
\hline \multirow[t]{2}{*}{ Typ gospodarstwa } & \multirow[t]{2}{*}{ PL } & \multicolumn{4}{|c|}{ Region } \\
\hline & & A & $\mathrm{B}$ & $\mathrm{C}$ & $\mathrm{D}$ \\
\hline \multicolumn{6}{|c|}{ Wartość produkcji ogółem [zł] } \\
\hline Ogółem & 134557 & 203027 & 210091 & 104133 & 77245 \\
\hline Uprawy polowe & 126846 & 221090 & 155283 & 75349 & 71252 \\
\hline Uprawy ogrodnicze & 221352 & 343706 & 272629 & 176754 & 224142 \\
\hline Uprawy trwałe & 101576 & 61430 & 142714 & 102890 & 89996 \\
\hline \multicolumn{6}{|c|}{ Koszty ogółem [zł] } \\
\hline Ogółem & 120487 & 181845 & 195439 & 89868 & 68244 \\
\hline Uprawy polowe & 115993 & 199743 & 144824 & 67237 & 65636 \\
\hline Uprawy ogrodnicze & 166937 & 268259 & 210016 & 132362 & 164369 \\
\hline Uprawy trwałe & 87345 & 73744 & 100441 & 89480 & 76839 \\
\hline \multicolumn{6}{|c|}{ Dochód na gospodarstwo [zł] } \\
\hline Ogółem & 38357,5 & 67318,5 & 46626,5 & 33882,0 & 22797,5 \\
\hline Uprawy polowe & 46002,5 & 85591,5 & 48053,0 & 31748,0 & 27452,5 \\
\hline Uprawy ogrodnicze & 61229,5 & 90404,0 & 68962,0 & 52367,5 & 63895,0 \\
\hline Uprawy trwałe & 30114,5 & 27687,0 & 68205,0 & 27675,0 & 24662,0 \\
\hline \multicolumn{6}{|c|}{ Dochód na osobę [zt] } \\
\hline Ogółem & 24860,0 & 35975,0 & 32372,0 & 22342,0 & 15745,5 \\
\hline Uprawy polowe & 31526,5 & 47726,0 & 37014,0 & 23548,0 & 20085,5 \\
\hline Uprawy ogrodnicze & 38720,0 & 50731,5 & 45812,5 & 32887,0 & 39532,5 \\
\hline Uprawy trwałe & 21318,5 & 21552,0 & 61021,0 & 19503,0 & 16175,5 \\
\hline \multicolumn{6}{|c|}{ Wartość przyznanej jednolitej płatności obszarowej [zł] } \\
\hline Ogółem & 17276 & 33486,5 & 23848,5 & 13500,5 & 9176 \\
\hline Uprawy polowe & 25542 & 48638,5 & 29043 & 15409 & 13826,5 \\
\hline Uprawy ogrodnicze & 4898 & 9120 & 4940,5 & 5748,5 & 2900,5 \\
\hline Uprawy trwałe & 8561,5 & 18954 & 11640,5 & 8078 & 6785 \\
\hline
\end{tabular}

Źródło: jak w tab. 3.

wartość produkcji roślinnej była jeszcze wyższa i wynosiła odpowiednio 99,0\% w gospodarstwach ogrodniczych oraz $98,2 \% \mathrm{w}$ gospodarstwach z dominacją upraw trwałych. W przypadku gospodarstw ogółem wartość produkcji z produkcji roślinnej stanowiła średnio w kraju zaledwie $50,3 \%$, natomiast z produkcji zwierzęcej oraz pozostałej pochodziło $49,7 \%$. Wynika to ze struktury uprawianych roślin oraz liczby zwierząt utrzymywanych $\mathrm{w}$ gospodarstwie. Struktura produkcji w danym typie produkcyjnym była zbliżona w poszczególnych regionach FADN, przy czym w gospodarstwach ogółem około 50-procentowy udział produkcji roślinnej w produkcji ogółem średnio w kraju wynikał z niższego udziału od przeciętnego w regionie C, gdzie wynosił $44,9 \%$. 


\section{KOSZTY}

W analizie kosztów (tab. 4.) w gospodarstwach w poszczególnych regionach kraju zwraca uwagę fakt, że wytworzenie wyższej wartości produkcji w gospodarstwach w regionie A i B w porównaniu z gospodarstwami w pozostałych regionach (niezależnie od ich nastawienia produkcyjnego, z wyjątkiem gospodarstw z dominacją upraw trwałych) wiązało się ze znacznie wyższym poziomem kosztów ogółem, przy czym najwyższe koszty w tych regionach były ponoszone przez gospodarstwa $\mathrm{z}$ najwyższą wartością produkcji (gospodarstwa ogrodnicze). Wyższa wartość produkcji gospodarstw ogrodniczych wiązała się przede wszystkim z poniesieniem przez nie większych kosztów bezpośrednich, tj. kosztów zakupu środków produkcji, takich jak nasiona, nawozy, środki ochrony roślin.

Podobnie jak w przypadku poprzedniej zmiennej charakteryzującej wyniki ekonomiczne gospodarstwa, tj. wartość produkcji, tak w przypadku kosztów potrzebnych na jej wytworzenie $\mathrm{w}$ gospodarstwach nastawionych na produkcję upraw polowych w regionie Pomorze i Mazury (region A) poniesione koszty ogółem były wyższe od kosztów w gospodarstwach ogółem o 9,8\%. Najwyższe koszty ogółem (niezależnie od regionu) przypadały jednak na gospodarstwa ogrodnicze.

W strukturze kosztów ogółem w gospodarstwach z produkcją polową oraz ogrodniczych (średnio we wszystkich regionach) dominowało zużycie pośrednie, obejmujące koszty bezpośrednie (z uwzględnieniem produktów wytworzonych i zużytych w procesie produkcji w gospodarstwie rolnym) oraz koszty ogólnogospodarcze towarzyszące działalności operacyjnej w roku obrachunkowym. Stanowiły one przeciętnie około $70 \%$ wartości kosztów (rys. 1.). Udział kosztów bezpośrednich w tych gospodarstwach stanowił średnio 41\%. Udział pozostałych kosztów, tj. amortyzacji oraz kosztów czynników zewnętrznych (wynagrodzenia, czynsze, odsetki) wynosił w gospodarstwach z produkcją polową odpowiednio 20,0 i 10,8\%, natomiast gospodarstwach ogrodniczych 15,3 i 16,2\%. W gospodarstwach ogółem udział kosztów bezpośrednich był znacznie wyższy, malało zaś znaczenie kosztów ogólnogospodarczych w zużyciu pośrednim, tj. kosztów utrzymania maszyn i budynków oraz energii, usług itp. Nieco inaczej natomiast kształtowała się struktura kosztów w gospodarstwach z uprawami trwałymi, w przypadku których amortyzacja stanowiła największy odsetek kosztów, natomiast udział pozostałych kosztów (koszty bezpośrednie, ogólnogospodarcze oraz koszty czynników zewnętrznych) był podobny.

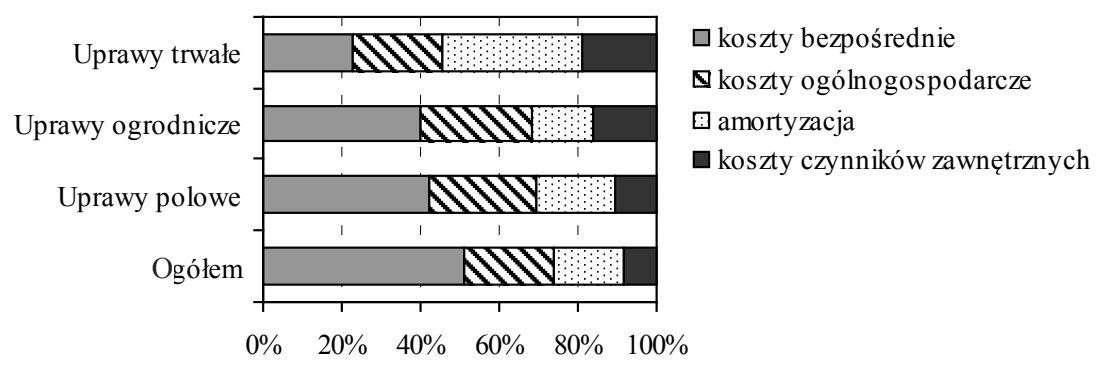

Rysunek 1. Struktura kosztów gospodarstw z produkcją roślinną oraz w gospodarstwach ogółem w Polsce (średnio z lat 2013 i 2014) według typów produkcyjnych

Źródło: jak w tab. 3. 


\section{DOCHÓD}

Najwyższy dochód z rodzinnego gospodarstwa rolnego w poszczególnych typach $\mathrm{z}$ produkcją roślinną oraz $\mathrm{w}$ gospodarstwach ogółem zanotowano $\mathrm{w}$ gospodarstwach ogrodniczych, które przeciętnie w Polsce uzyskały kwotę 61 tys. zł, (38 tys. zł dochód wypracowany przez gospodarstwa ogółem). Występowało jednak zróżnicowanie regionalne. W dwóch regionach kraju, tj. C i D, dochód uzyskany w gospodarstwach ogrodniczych był zdecydowanie wyższy niż w gospodarstwach ogółem oraz w pozostałych typach $\mathrm{z}$ produkcją roślinną średnio odpowiednio aż o 168,4 i 255,9\%. Odmiennie sytuacja kształtowała się w gospodarstwach w regionie A (Pomorze i Mazury), w którym najkorzystniej pod względem wysokości uzyskanego dochodu nadal wypadły gospodarstwa ogrodnicze, jednak dochód w gospodarstwach z uprawami polowymi był tylko o 5\% niższy, natomiast dochód w gospodarstwach $\mathrm{z}$ dominacją upraw trwałych w pozostałym objętym badaniem typie roślinnym oraz w gospodarstwach ogółem stanowił średnio 55,5\% wartości dochodu gospodarstw o największym udziale $\mathrm{w}$ wartości produkcji upraw polowych. $\mathrm{Z}$ kolei $\mathrm{w}$ regionie $\mathrm{B}$ dochód wypracowany przez gospodarstwa $\mathrm{z}$ dominacją upraw trwałych był porównywalny z dochodem uzyskanym przez gospodarstwa ogrodnicze, natomiast gospodarstwa $z$ uprawami polowymi oraz gospodarstwa ogółem charakteryzowały się dochodem niższym średnio o około 45\%. Należy zaznaczyć, że region A z uwagi na kryterium dochodu ma najbardziej korzystne warunki dla produkcji polowej w porównaniu z produkcją tych upraw w analogicznej grupie gospodarstw w pozostałych regionach, które dla tego typu gospodarstw wydają się mniej sprzyjające do uzyskania zadowalającego dochodu. Kluczowe znaczenie ma w nich struktura agrarna gospodarstw rolnych (posiadane zasoby ziemi).

Podobne różnice między gospodarstwami zaznaczyły się w dochodzie przeliczonym na osobę pełnozatrudnioną rodziny rolnika (tab. 4.). Gospodarstwa z produkcją polową w regionie Pomorze i Mazury uzyskały dochód na podobnym poziomie jak gospodarstwa ogrodnicze, tj. około 49 tys. zł na członka rodziny zatrudnionego w pełnym wymiarze czasu pracy. W regionie B najwyższy dochód uzyskali członkowie rodzin trudniących się produkcją upraw trwałych. W pozostałych regionach (C i D) poziom dochodu utrzymywał podobne zależności, tzn. największy osiągały osoby z rodziny producentów warzyw i kwiatów, niższy średnio o $60,3 \%$ członkowie rodzin prowadzących uprawę zbóż i rzepaku, natomiast zdecydowanie najniższy dochód przypadł na pracujących przy produkcji upraw trwałych (sadów i plantacji wieloletnich). Najmniejsze różnice pod względem wysokości uzyskanego dochodu pomiędzy analizowanymi typami gospodarstw występowały w regionie $\mathrm{C}$, natomiast największe zróżnicowanie odnotowano $\mathrm{w}$ regionie $\mathrm{D}$, gdzie dochód $\mathrm{w}$ gospodarstwach $\mathrm{z}$ uprawami polowymi stanowił jedynie 50\% dochodu wypracowanego przez członków rodzin gospodarstw ogrodniczych. Członkowie rodziny rolnika zatrudnieni w pełnym wymiarze czasu pracy $\mathrm{w}$ gospodarstwach $\mathrm{w}$ regionie $\mathrm{D}$ uzyskiwali najniższe wynagrodzenie, $\mathrm{z}$ wyjątkiem gospodarstw ogrodniczych, w których dochód był najbardziej stabilny niezależnie od regionu.

\section{DOPŁATY}

Od momentu wstąpienia Polski do UE bardzo ważną składową mającą wpływ na osiągane dochody przez gospodarstwo rolne są także dopłaty pozyskane w ramach prowadzonej działalności operacyjnej. Należy zatem mieć na uwadze, że wysokość dochodu uzyskanego przez gospodarstwo rolne nie wynika jedynie z wartości produkcji pomniejszonej o koszty jej wytworzenia. 
Udział dopłat w dochodzie na gospodarstwo rolne (tab. 5.) przeciętnie w gospodarstwach z produkcją polową kształtował się na poziomie 101,5\% (od 86,1\% w $2014 \mathrm{r}$. do $116,9 \%$ w 2013 r.) i był najwyższy w porównaniu z gospodarstwami w pozostałych analizowanych typach oraz gospodarstwach ogółem. W gospodarstwach z dominacją upraw trwałych udział dopłat w dochodzie wynosił 77,9\%, jednak ich udział wzrósł $\mathrm{z}$ $42,9 \%$ w 2013 r. do 112,9\% w 2014 r. W gospodarstwach ogrodniczych udział subwencji był najniższy $(12,2 \%)$, natomiast średnio w gospodarstwach ogółem w Polsce wynosił $85,4 \%$. Zatem gospodarstwa ogrodnicze otrzymywały stosunkowo niewielkie dopłaty na tle pozostałych typów z produkcją roślinną, które nie wywierały znaczącego wpływu na dochody uzyskane w tych gospodarstwach. Najwyższy stosunek dopłat w dochodzie dla gospodarstw znajdujących się w dwóch typach produkcyjnych (,uprawy polowe” i , uprawy trwałe") i gospodarstw ogółem w Polsce obserwowano w gospodarstwach położonych w regionie A (Pomorze i Mazury), gdzie pozyskane dopłaty w wartości dochodu stanowiły odpowiednio 116,7, 146,2 i 106,8\%. Wyjątek to gospodarstwa ogrodnicze, gdzie udział dopłat w dochodzie był największy w regionie Mazowsze i Podlasie. Największy udział dopłat pozyskanych do działalności operacyjnej (średnio z wszystkich typów roślinnych oraz gospodarstw ogółem) zanotowano dla gospodarstw w regionie Pomorze i Mazury, natomiast najmniejszy w gospodarstwach w regionie Wielkopolska i Śląsk. W odniesieniu do danego typu największe różnice w poszczególnych regionach występowały w gospodarstwach z uprawami trwałymi, a najmniejsze z produkcją ogrodniczą. O ile w przypadku gospodarstw z produkcją upraw trwałych różnice w relacji dopłat do dochodu w poszczególnych regionach były kilkudziesięcioprocentowe, o tyle w gospodarstwach ogrodniczych sięgały zaledwie kilkunastu procent. Należy dodać, że w regionie A w gospodarstwach wyspecjalizowanych w uprawach polowych oraz w uprawie sadów i plantacji wieloletnich wartość dopłat przekraczała wartość uzyskanej produkcji pomniejszonej o koszty jej wytworzenia. Sytuacji takiej nie zaobserwowano w innych regionach kraju.

Tabela 5. Udział dopłat w dochodzie w badanych typach gospodarstw z produkcją roślinną i ogółem w Polsce

\begin{tabular}{llrrrrr}
\hline Lata & Typ & \multicolumn{5}{c}{ Udział dopłat w dochodzie [\%] } \\
\cline { 3 - 6 } & & \multicolumn{1}{c}{ PL } & \multicolumn{1}{c}{ A } & \multicolumn{1}{c}{ B } & C & \multicolumn{1}{c}{ D } \\
\hline \multirow{3}{*}{2013} & ogółem & 101,3 & 138,7 & 114,7 & 82,9 & 86,5 \\
& uprawy polowe & 116,9 & 150,5 & 113,2 & 95,6 & 99,7 \\
& uprawy ogrodnicze & 16,6 & 13,1 & 13,6 & 25,3 & 9,4 \\
& uprawy trwałe & 42,9 & - & 26,3 & 39,9 & 36,2 \\
\hline \multirow{4}{*}{2014} & ogółem & 69,5 & 74,9 & 70,0 & 65,9 & 70,6 \\
& uprawy polowe & 86,1 & 82,9 & 85,6 & 88,0 & 96,5 \\
& uprawy ogrodnicze & 12,2 & 24,6 & 11,5 & 16,1 & 6,4 \\
& uprawy trwałe & 112,9 & 146,2 & 63,4 & 119,2 & 110,9 \\
\hline \multirow{4}{*}{ Średnio } & ogółem & 85,4 & 106,8 & 92,4 & 74,4 & 78,5 \\
& uprawy polowe & 101,5 & 116,7 & 99,4 & 91,8 & 98,1 \\
& uprawy ogrodnicze & 14,4 & 18,8 & 12,5 & 20,7 & 7,9 \\
& uprawy trwałe & 77,9 & 146,2 & 44,8 & 79,5 & 73,6 \\
\hline
\end{tabular}

Źródło: jak w tab. 3. 
Wysoki udział dopłat w dochodzie w gospodarstwach z dominacją produkcji polowej oraz w gospodarstwach ogółem wynika przede wszystkim z wartości pozyskanych dopłat w formie tzw. jednolitej płatności obszarowej (JPO), której wysokość zależy od powierzchni użytków rolnych w gospodarstwie. W 2013 r. stawka JPO wynosiła 830,30 zł/ha [Rozporządzenie z 2013 r Dz.U. z 2015 r., poz. 1334], natomiast w 2014 r. 910,87 zł/ha [Rozporządzenie z 2014 r. Dz.U. z 2014 r., poz. 1602].

\section{PODSUMOWANIE}

Monitorowanie sytuacji ekonomicznej, w tym dochodowości gospodarstw rolnych grupowanych według kryterium typu rolniczego, stwarza możliwość określenia opłacalności poszczególnych działalności rolnych i ułatwia podjęcie decyzji o ewentualnym przestawieniu gospodarstwa. Przestawienie to wiąże się jednak z umiejętnym zarządzaniem, a niekiedy wymusza zmianę wyposażenia technicznego gospodarstwa. Należy zauważyć, że od momentu przynależności Polski do UE wysokość dochodu uzyskanego przez gospodarstwo rolne nie wynika jedynie z wartości produkcji pomniejszonej o koszty jej wytworzenia, lecz zależy również od wysokości dopłat pozyskanych w ramach prowadzonej działalności operacyjnej.

Z przeprowadzonych badań wynika, że sytuację ekonomiczną gospodarstw w dwóch analizowanych typach z produkcją roślinną (,uprawy polowe”, „uprawy trwałe”) kształtował głównie system dopłat, natomiast w gospodarstwach ogrodniczych rynek. Poruszono ten problem przy okazji badań sytuacji ekonomicznej gospodarstw ogrodniczych na tle gospodarstw ogółem w 2010 r. [Figura 2012]. Szczególnie trudna sytuacja wystąpiła w gospodarstwach nastawionych na uprawy polowe, w których uzyskana nadwyżka z prowadzonych działalności (zboża, rzepak) średnio w kraju wynosiła około 11 tys. zł. Niewiele korzystniejszą sytuację obserwowano w gospodarstwach ukierunkowanych na produkcję upraw trwałych (sadów i plantacji wieloletnich), w których nadwyżka wyniosła nieco ponad 14 tys. zł, podczas gdy w gospodarstwach ogrodniczych, uzyskana wartość produkcji przewyższała koszty o ponad 54 tys. zł.

W sytuacji, gdy dochodowość większości gospodarstw rolnych jest warunkowana przez system dopłat, a nie rynek, zachodzi konieczność ograniczania kosztów, gdyż gospodarstwo rolne, jak podała Katarzyna Smędzik, z ekonomicznego punktu widzenia jest tym bardziej efektywne, im dla osiągnięcia założonego celu zużywa mniejsze wielkości nakładów bądź przy danych nakładach osiąga coraz lepszy wynik produkcyjny [Smędzik 2012]. W gospodarstwach z dominacją upraw polowych poprawa sytuacji możliwa jest np. przez zmianę techniki uprawy polegającej na stosowaniu uproszczonych systemów uprawy roli, tj. zastępowanie tradycyjnego systemu płużnego uprawą bezorkową oraz siewem bezpośrednim. Należy dodać, że wytworzenie produktu głównego (plonu) uprawianych roślin uzyskuje się wówczas przy znacząco mniejszych nakładach energii na uprawę roli [Kordas 1999], natomiast efekty produkcyjne mogą być wyższe, niejednokrotnie pomimo niższych plonów. 


\section{LITERATURA}

Cholewa Izabela, Katarzyna Kambo, 2016: Wyniki standardowe 2014 uzyskane przez gospodarstwa rolne uczestniczace w Polskim FADN Region FADN 795 Mazowsze i Podlasie. Czesść I. Wyniki standardowe, IERiGŻ-PIB, Warszawa, s. 1-61.

Figura Michał, 2012: Sytuacja ekonomiczno-finansowa towarowych gospodarstw ogrodniczych w Polsce na tle gospodarstw ogótem w 2010 roku. „Roczniki Naukowe SERiA”, t. XIV, z. 1, s. 140-145.

Floriańczyk Zbigniew, Dariusz Osuch, Renata Płonka, 2016: Wyniki standardowe 2014 uzyskane przez gospodarstwa rolne uczestniczace w Polskim FADN. Część I. Wyniki standardowe, IERiGŻ-PIB, Warszawa, s. 1-62.

Goraj Lech, Izabela Cholewa, Dariusz Osuch, Renata Płonka, 2010: Analiza skutków zmian we Wspólnotowej Typologii Gospodarstw Rolnych, IERiGŻ-PIB, Warszawa, s. 12.

Goraj Lech, Rafał Tarasiuk, 2016: Wyniki standardowe 2014 uzyskane przez gospodarstwa rolne uczestniczace w Polskim FADN Region FADN 800 Małopolska i Pogórze. Część I. Wyniki standardowe, IERiGŻ-PIB, Warszawa, s. 1-61.

Kordas Leszek, 1999: Energochłonność i efektywność różnych systemów uprawy roli w zmianowaniu, „Folia Universitis Agriculturae Stetinesis. Agriculura”, 74, s. 47-52.

Mikołajczyk Irena, Alicja Wituszyńska, 2016: Wyniki Standardowe 2014 uzyskane przez gospodarstwa rolne uczestniczace w Polskim FADN Region FADN 785 Pomorze i Mazury. Część I. Wyniki standardowe, IERiGZ-PIB, Warszawa, s. 1-61.

Puchalska Monika, Adam Smolik, Justyna Żurakowska, 2016: Wyniki standardowe 2014 uzyskane przez gospodarstwa rolne uczestniczace w Polskim FADN Region FADN 790 Wielkopolska i Śląs. Czesść I. Wyniki standardowe, IERiGŻ-PIB, Warszawa, s. 1-61.

Rozporzadzenie Ministra Rolnictwa i Rozwoju Wsi z dnia 14 listopada 2013 r. w sprawie stawki jednolitej płatności obszarowej za 2013 r. Dz.U. z 2015 r., poz. 1334.

Rozporzadzenie Ministra Rolnictwa i Rozwoju Wsi z dnia 7 listopada 2014 r. w sprawie stawki jednolitej ptatności obszarowej za 2014 r. Dz.U. z 2014 r., poz. 1602.

Smędzik Katarzyna, 2012: Czynniki wpływajace na efektywność techniczna gospodarstw rolnych osób fizycznych, wyspecjalizowanych w produkcji zwierzęcej (na przyktadzie gospodarstw Polskiego FADN z powiatu gostyńskiego), „Journal of Agribusiness and Rural Development”, 3(25), s. 241-250.

\section{Michat Figura \\ ECONOMIC AND FINANCIAL RESULTS OF FARMS WITH FIELD CROPS AGAINST FARMS FOCUSED ON THE REMAINING CROPS AND THE TOTAL FARMS IN POLAND BASED ON POLISH FADN DATA}

\section{Summary}

The paper presents the results of economic and financial farms focused on the cultivation of field crops against farms targeted for the remainder of plant production (horticulture, permanent crops), and the total households in Poland. The basis of the study were data from the 2013 and 2014 year collected in these farms, under a system of Polish FADN. It has been shown that the holding in which the dominant share in the total production is the cultivation of field crops (mainly cereals and rape) were characterized by an average of approx. 20\% higher income than households in general. In terms of income, however, is dominated by horticultural holdings. There are in this issue are some differences depending on the region FADN. Among the types of productive horticultural holdings are characterized by relatively low value obtained subsidies that in other types of vegetable farms and in general they have a significant impact on earned income. If the payments stopped functioning farm with permanent crops in the region of Pomerania and Masuria did not have to exist.

Adres do korespondencji:

Mgr inż. Michał Figura

Szkoła Główna Gospodarstwa Wiejskiego w Warszawie Wydział Rolnictwa i Biologii, Katedra Agronomii 02-776 Warszawa, ul. Nowoursynowska 159 e-mail: michalf6@o2.pl 